Original Research Article

\title{
Invitro antibacterial activity of Cassia fistula Linn methanolic leaf extracts
}

\author{
Bindhu R. Kamath, Sabeena Kizhedath*
}

Department of Pharmacology, Government Medical College, Kerala, Ernakulam, India

Received: 01 December 2018 Accepted: 28 December 2018

\section{*Correspondence to:}

Dr. Sabeena Kizhedath, Email: drsabeenakizhedath@ gmail.com

Copyright: (C) the author(s), publisher and licensee Medip Academy. This is an openaccess article distributed under the terms of the Creative Commons Attribution NonCommercial License, which permits unrestricted noncommercial use, distribution, and reproduction in any medium, provided the original work is properly cited.

\begin{abstract}
Background: Cassia fistula Linn is a plant which is widely grown in India and is used for medicinal purposes. The study was carried out with an objective to demonstrate the antimicrobial activity of leaves of Cassia fistula Linn. The aim of the study is to assess antibacterial and antifungal activity of methanolic leaf extract of Cassia fistula Linn against selected clinical isolates.

Methods: The antimicrobial activity of methanolic extract of Cassia fistula was evaluated using agar well diffusion method and to zone of inhibition of extract was determined. Clinical isolates of Staphyloccocus aureus, MRSA, Pseudomonas aeruginosa, E. coli and Proteus were screened.

Results: The methanolic extracts exhibited antibacterial activity against Staphylococcus aureus. The extract was not active against E. coli, Proteus, MRSA, Pseudomonas aeruginosa. The extract also failed to demonstrate antifungal activity against Candida albicans and Aspergillus niger.

Conclusions: The global emergence of multidrug resistant bacterial strains is increasing, limiting the effectiveness of current drugs and treatment failure of infections. A novel approach to the prevention of antibiotic resistance of pathogenic species is the use of new compounds that are not based on existing synthetic antimicrobial agents.
\end{abstract}

Keywords: Aspergillus niger, Cassia fistula, Candida albicans, Dimethyl sulfoxide, E coli, Methicillin resistant staphylococcus aureus, Pseudomonas aeruginosa, Proteus, Staphylococcus aureus

\section{INTRODUCTION}

Over the last few years, researchers have aimed at identifying and validating plant-derived substances for the treatment of various diseases. Interestingly it is estimated that nearly $25 \%$ of the modern medicines are directly or indirectly derived from plants. It is worth mentioning that Indian medicinal plants are considered as a vast source of several pharmacological principles and compounds that are commonly used as home remedies against multiple ailments. ${ }^{1}$

With the emerging worldwide interest in adopting and studying traditional systems and exploiting their potential based on different health care systems, the evaluation of the rich heritage of traditional medicine is essential. ${ }^{1}$ The pharmaceutical industries have produced a number of new antibiotics; resistance to these drugs by microorganisms has increased..$^{2}$ The indiscriminate and irrational use of antibiotics these days has led to the evolution of new resistant strains of bacteria that are somewhat more lethal compared to the parent strain. Cases of widespread occurrence of resistant bacteria are now very common which leads to many health-related problems. ${ }^{3}$ Change in the genetic constitution of resistant bacteria is so rapid that the effectiveness of common antibiotics may be lost within a period of 5 years. ${ }^{4}$ As per the report of the WHO (World Health Organization) resistance was more prevalent in cases of bacteria which cause most of the deadly infections worldwide such as respiratory tract infections, diarrhoea, meningitis and tuberculosis. ${ }^{5}$ Staphylococcus aureus isolated from clinical samples are now showing resistance 
to more than three drugs and are considered as multipledrug resistant bacteria. ${ }^{6}$

Nowadays, researchers are in search of some novel antimicrobial molecules which have a broad spectrum of activity against both gram-negative and gram-positive bacteria without having many or any side effects. They are exploring the variety of medicinal plants which are described in Ayurveda. ${ }^{7}$ In recent years, the research on plant-based drugs has increased tremendously and there is some hope seen in certain medicinal plants which can be used for the treatment of these incurable diseases.

Over the past few decades many commonly used antibiotics have become less and less effective against infections because of emergence of drug resistant bacteria. ${ }^{8}$ So the need of the hour is to find an alternative drug with less resistance. In many developing countries majority of population depend on traditional medicines for their illness. ${ }^{9}$ The curative potential of herbal medicines are well documented from time immemorial. ${ }^{10}$

Cassia fistula Linn (leguminosae), Indian Laburnum (Golden shower tree) a very common plant known for its medicinal properties. Cassia fistula plant and its extracts is also used as a pest controlling agent in India. ${ }^{11}$ Cassia fistula has also shown to exert significant antipyretic and analgesic effect. ${ }^{12}$

The plant has been reported to possess antimicrobial properties by different studies conducted in India as well as other countries. Plants growing in different climatic and seasonal conditions do not have identical constituents or therapeutic effects. ${ }^{13}$ Thus active components may differ in nature or concentration. Phytochemical analysis of the crude extracts can indicate the presence of active constituents in the plant. In the present investigation, a screening of methanolic extract of Cassia fistula leaves against clinical isolates of pathogens like Staphylococcus aureus, MRSA, Pseudomonas aeurginosa, E. coli, Proteus, Candida albicans, Aspergillus niger were done.

\section{METHODS}

\section{Collection of plant materials}

Fresh leaves of Cassia fistula were collected from GMC, Ernakulam campus in month of May- June. Leaves were shade dried and crushed into fine powder with electric blender. The powdered sample were sealed in polythene box and stored. The plant was authenticated as Cassia fistula Linn from the department of Dravya Guna, PNNM Ayurveda College, Cheruthuruty, Shornur, Kerala.

\section{Preparation of methanolic extracts: sample preparation}

\section{Preparation of methanol extract}

Dried and powdered leaves (25g) were used. The extract was prepared using Soxhlet apparatus. Powdered leaves with $200 \mathrm{ml}$ of methanol was subjected for extraction for about $10 \mathrm{hr}$ in a water bath. The crude plant extract in solvent was removed from the Soxhlet apparatus and concentrated to dryness in water bath and is stored in refrigerator.

\section{Phytochemical screening}

Preliminary phytochemical screening was performed by using standard tests.

Test for alkaloids was done using Dragendroff's test. To $1 \mathrm{ml}$ of extract, $1 \mathrm{ml}$ of reagent was added. Yellow precipitate was obtained. To $1 \mathrm{ml}$ of extract, $1 \mathrm{ml}$ of water and $1 \mathrm{ml}$ of Aq. $\mathrm{NaOH}$ was added. Yellowish brown precipitate was obtained which confirmed the presence of Glycosides. Presence of Flavanoids was confirmed by adding $1 \mathrm{ml}$ of $10 \%$ lead acetate to $1 \mathrm{ml}$ of the extract with the appearance of yellowish green precipitate.

A froth was obtained by boiling $1 \mathrm{ml}$ of extract with $1 \mathrm{ml}$ of distilled water which confirmed the presence of saponins. Few drops of $0.1 \% \mathrm{Fecl}_{3}$ was added to $1 \mathrm{ml}$ extract. A brownish green precipitate was formed confirming the presence of tannins. A brown precipitate was obtained on adding $1 \mathrm{ml}$ of $\mathrm{CHCl}_{3}, 2 \mathrm{ml}$ conc. $\mathrm{H}_{2} \mathrm{SO}_{4}$. To $1 \mathrm{ml}$ of extract indicating the presence of terpenoids

To $1 \mathrm{ml}$ of extract was added $1 \mathrm{ml}$ of $40 \% \mathrm{NaOH}$ and 2 drops of $1 \% \mathrm{CuSO}_{4}$. A pink colour was obtained indicating the presence of proteins. Benedict's test: was performed with $1 \mathrm{ml}$ extract. A slight red precipitate was obtained showing the presence of carbohydrates.

\section{Antimicrobial analysis}

\section{Materials and Methods}

\section{Media used}

Mueller-Hinton Agar (Himedia)

\section{Antimicrobial analysis}

\section{Media preparation and antimicrobial analysis}

$3.8 \mathrm{~g}$ of Mueller-Hinton Agar was dissolved in $100 \mathrm{ml}$ distilled water. Sterilized by autoclaving at $121^{\circ} \mathrm{C}$ for 15 minutes at $15 \mathrm{lbs}$ pressure. After sterilization media was cooled to $45^{\circ} \mathrm{C}$ in water bath. Then $25 \mathrm{ml}$ media was poured in to sterile petri plates and allowed to solidify. After that, 3 hrs old bacterial culture was swabbed on the surface of MHA plates and kept for drying the inoculum. Then, using sterile cork borer of $8 \mathrm{~mm}$ diameter, wells were prepared on the agar media, $100 \mathrm{mcl}$ sample of different concentrations were taken, Cassia fistula Linn methanolic leaf extract and was added to the well. Gentamicin was kept as control. After the complete diffusion of sample in to the agar well, the plates were kept 
for incubation at $37^{\circ} \mathrm{C}$ for $24 \mathrm{hrs}$. After incubation, zone of inhibition was measured.

\section{RESULTS}

Cassia fistula Linn is known to have antibacterial activity and is used as a traditional medicine. In the present study phytochemical analysis of the methanolic extract of plant exhibited presence of alkaloids, flavonoids, glycosides, tannins, saponins, terpenoids, proteins, carbohydrates. Antimicrobial screening was done prior to antimicrobial assay. Antibacterial potential of the extract was assessed in extract of Cassia fistula exhibited significant antibacterial activity against clinical isolate of gram-positive bacteria Staphylococcus aureus.

\section{Table 1: Phytochemical analysis of Cassia fistula} leaf extract.

\begin{tabular}{|ll|}
\hline Phytochemical constituent & Cassia fistula \\
\hline Alkaloids & + \\
\hline Glycosides & + \\
\hline Flavanoids & + \\
\hline Saponins & + \\
\hline Tannins & + \\
\hline Terpenoids & + \\
\hline Proteins & + \\
\hline Carbohydrates & + \\
\hline
\end{tabular}

The inhibition zone diameter was about $11 \mathrm{~mm}$ against clinical isolate of Staphylococcus aureus. The zone was obtained in a concentration of $50 \mu \mathrm{g} / \mu \mathrm{l}$. Gentamicin was terms of zone of inhibition of bacterial growth. Methanolic

used as the standard antibiotic. The zone of inhibition obtained for the standard was $5 \mu \mathrm{g} / \mu \mathrm{l}$. In the present study activity of crude extract of Cassia fistula Linn leaves was analysed against other microbes also. The extract failed to show antibacterial activity against MRSA, Pseudomonas aeruginosa, E. coli, Proteus. The extract also failed to demonstrate antifungal activity against the tested clinical isolates of Candida albicans and Aspergillus niger.

Table 1 Shows phytochemical analysis of Cassia fistula Linn. Analysis confirmed the presence of alkaloids, glycosides, flavonoids, saponins, tannins, terpenoids, proteins and carbohydrates.

Table 2: Cassia fistula antibacterial activity against clinical isolates.

\begin{tabular}{|ll|}
\hline Microorganism & Sensitivity \\
\hline Staphylococcus aureus & + \\
\hline MRSA & - \\
\hline E. coli & - \\
\hline Pseudomonas aeruginosa & - \\
\hline Proteus & - \\
\hline
\end{tabular}

+ indicates presence; - indicate absence

Table 2 shows Cassia fistula antibacterial activity against clinical isolates. It shows antibacterial activity of methanolic extract of Cassia fistula against Staphylococcus aureus. It failed to demonstrate activity against MRSA, Pseudomonas aeruginosa, E. coli, Proteus. The extract also failed to demonstrate antifungal activity against the tested clinical isolates of Candida albicans and Aspergillus niger.

Table 3: Anti staphylococcal of activity (zone of inhibition in mm) of Cassia fistula.

\begin{tabular}{|c|c|c|c|c|c|}
\hline Micro-organism & $10 \mu \mathrm{g} / \mu \mathrm{l}$ & $20 \mu \mathrm{g} / \mu \mathrm{l}$ & $30 \mu \mathrm{g} / \mu \mathrm{l}$ & $40 \mu \mathrm{g} / \mu \mathrm{l}$ & $50 \mu \mathrm{g} / \mu \mathrm{l}$ \\
\hline $\begin{array}{l}\text { Clinical isolate } \\
\text { Staph aureus }\end{array}$ & No zone & No zone & No zone & No zone & $11 \mathrm{~mm}$ \\
\hline
\end{tabular}

Table 3 shows anti staphylococcal of activity (zone of inhibition in $\mathrm{mm}$ ) of Cassia fistula Linn. No zone of inhibition was obtained for the concentrations $10 \mu \mathrm{g} / \mu \mathrm{l}$, $20 \mu \mathrm{g} / \mu \mathrm{l}, 30 \mu \mathrm{g} / \mu \mathrm{l}, 40 \mu \mathrm{g} / \mu \mathrm{l}$. Zone of inhibition of $11 \mathrm{~mm}$ was obtained at $50 \mu \mathrm{g} / \mu \mathrm{l}$ concentration.

Table 4: Zone of inhibition of antibiotic gentamicin.

\begin{tabular}{|llll|}
\hline Microrganism & $1.25 \mu \mathrm{gg} / \mu \mathrm{l}$ & $\mathbf{2 . 5} \mathrm{\mu g} / \mathrm{\mu l}$ & $\mathbf{5} \boldsymbol{\mu \mathrm { g }} / \boldsymbol{\mu l}$ \\
\hline $\begin{array}{l}\text { Clinical isolate } \\
\text { Staph aureus }\end{array}$ & No zone & No zone & $28 \mathrm{~mm}$ \\
\hline
\end{tabular}

Table 4 shows zone of inhibition of antibiotic gentamicin. Gentamicin was as control for the analysis. At a concentration of $5 \mu \mathrm{g} / \mu \mathrm{l}$, zone of inhibition of $28 \mathrm{~mm}$ was noted. It failed to show inhibition at lower concentrations.

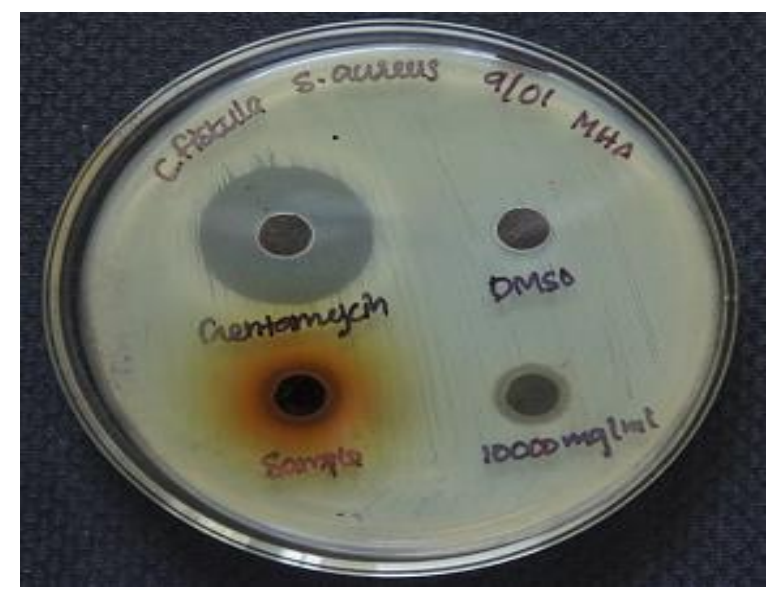

Figure 1: Antibacterial activity of Cassia fistula against Staphylococcus aureus. 
Figure 1 shows antibacterial activity of Cassia fistula against clinical isolate of Staphylococcus aureus using disc diffusion method. Gentamicin was used as standard which exhibited a zone of inhibition of $28 \mathrm{~mm}$. DMSO was used solvent. Sample at $50 \mu \mathrm{g} / \mu \mathrm{l}$ concentration exhibited $11 \mathrm{~mm}$ zone of inhibition. At $10 \mu \mathrm{g} / \mu \mathrm{l}$ it failed to demonstrate any notable inhibition.

\section{DISCUSSION}

Worldwide use of plants and plant products for medicinal purpose are increasing day by day. The World Health Organization estimates that plant extract or their active constituents are used as folk medicine in $80 \%$ of the world's population. ${ }^{14}$ Cassia fistula Linn is known traditional medicine which is used in India for different ailments.

The present study showed the presence of different phytochemicals which are the bioactive components that can be of use. The result of phytochemicals in the present investigation showed that the plant contains components such as saponin, terpenoids, glycosides, flavonoids, gum, proteins and alkaloids

In the present study methanolic extract of Cassia fistula showed significant activity against clinical isolate of Staphylococcus aureus strain. The other clinical isolates of MRSA, Pseudomonas aeruginosa, E. coli, Proteus, Candida, Aspergillus tested were negative. The maximum concentration of extract $50 \mu \mathrm{g} / \mu \mathrm{l}$ showed significant antibacterial activity against staph aureus. Most of antimicrobial effects of Cassia fistula is related to the components and secondary metabolites like phenolic compounds. ${ }^{15}$ Phytochemical analysis of Cassia fistula indicated the presence of saponins, terpenoids, glycosides, and flavonoids etc. that inhibit the growth of Staphylococcus aureus strain. ${ }^{16}$

Vasudevan et al, in his study revealed that methanolic extracts of Cassia fistula inhibited gram positive bacteria than gram negative species. ${ }^{17}$ Significant activity of Cassia fistula species against gram positive bacteria was also demonstrated by Rizvi et al. ${ }^{18}$ The study conducted by Bhalodia et al, assessed the antimicrobial activity of Cassia fistula against antimicrobial agents. The study showed remarkable inhibition of bacterial growth of gram positive organisms like Staphylococcus aureus and streptococcus pyogenus. ${ }^{14}$ In the study conducted by Duraipandian et al, different extracts from the flower of Cassia fistula were tested against bacteria and fungi. All the extracts exhibited antibacterial activity against gram positive organism with MIC between 0.078 and $2.5 \mathrm{mg} / \mathrm{ml} .{ }^{19}$ Study done of Panda SK et al, showed that extracts of Cassis fistula Linn demonstrated food inhibitory activity against gram positive organisms. ${ }^{20}$ In a study conducted by Senthil Kumar M et al, the efficacy of Cassia fistula in the treatment of infected wound on albino rat model was confirmed. ${ }^{21}$ Another study reported that plant protease inhibitor fistulin to be very active against Staphylococcus aureus, E. coli, B. subtilis and K Pneumonia. ${ }^{22}$ Methanol extract of Cassia fistula seeds was found to have antibacterial activity. ${ }^{23}$

\section{CONCLUSION}

Antimicrobial resistance is the global problem. Therapeutic options are limited because of wide emergence of multidrug resistance. Hence novel medicine with lesser resistance and adverse effects are required. This study was aimed to focus on the antimicrobial properties of Cassia fistula Linn. From this study it is clear that crude extracts of Cassia fistula leaf contain medicinally active components. The preliminary phytochemical investigation confirms the presence of bioactive components in the extract. The result of this study on Cassia fistula methanolic leaf extract demonstrate significant antibacterial activity on Staphylococcus aureus by disc diffusion method. However, the components responsible for the antibacterial activity of methanolic extract are currently unclear. Therefore, it will be worthwhile to isolate the active fractions of Cassia fistula for further testing in order to prepare a good antimicrobial agent against Staphylococcus aureus.

Funding: No funding sources

Conflict of interest: None declared

Ethical approval: The study was approved by the Institutional Ethics Committee

\section{REFERENCES}

1. Danish M, Singh P, Mishra G, Srivastava S, Jha KK, Khosa RL. Cassia fistula Linn. (Amulthus)-An important medicinal plant: A review of its traditional uses, phytochemistry and pharmacological properties. J Nat Prod Plant Resour. 2011;1(1):101-18.

2. Lopez A, Hudson JB, Towers GH. Antiviral and antimicrobial activities of Colombian medicinal plants. J Ethnopharmacol. 2001 Oct 1;77(2-3):189-96.

3. Iwu M.W, Duncan A.R,Okunji C.O. New antimicrobials of plant orgin, In prespectives on New Crops and New Uses; Janick J ed; ASHS Press: Alexandria, VA, USA, 1999;457-462.

4. Bush K. Antibacterial drug discovery in the $21 \mathrm{st}$ century. Clin Microbiol Infection. 2004 Nov;10:10-7.

5. World Health Organization (WHO), Antimicrobial resistance, Fact sheet No. 194; WHO: Geneva, Switzerland, 2002.

6. Styers D, Sheehan DJ, Hogan P, Sahm DF. Laboratory-based surveillance of current antimicrobial resistance patterns and trends among Staphylococcus aureus: 2005 status in the United States. Ann Clin Microbiol Antimicrob. 2006 Jan;5(1):2.

7. Chandra H, Bishnoi P, Yadav A, Patni B, Mishra AP, Nautiyal AR. Antimicrobial resistance and the alternative resources with special emphasis on plantbased antimicrobials-a review. Plants. 2017 Apr 10;6(2):16. 
8. Farnsworth NR. Ethnopharmacology and future drug development: the North American experience. J Ethnopharmacol. 1993 Mar 1;38(2-3):137-43.

9. Houghton PJ. The role of plants in traditional medicine and current therapy. J Alternative Complementary Med. 1995 Jun 1;1(2):131-43.

10. Dubey NK, Kumar R, Tripathi P. Global promotion of herbal medicine: India's opportunity. Curr Sci. 2004 Jan 10;86(1):37-41.

11. Jaypal S, Sing Z, Chauhan R. Juvenile hormone like activity in extracts of some common Indian Plants. Indian J Agr Sci.1983;53:730-33.

12. Patel DG, Karbhari SS, Gulati OD, Gokhale SD. Antipyretic and analgesic activities of Aconitum spicatum and Cassia fistula. Int Arch Pharmacodynamics Therapy. 1965 Sep;157(1):22-7.

13. Agarwal SS, Paridhavi M, Introduction to medicinal plants. Herbal drug technology. 1st ed. 2007:3-4.

14. Bhalodia NR, Shukla VJ. Antibacterial and antifungal activities from leaf extracts of Cassia fistula 1.: An ethnomedicinal plant. J Advanced Pharmaceut Tech Res. 2011 Apr;2(2):104.

15. Bahorun T, Neergheen VS, Aruoma OI. Phytochemical constituents of Cassia fistula. African J Biotechnol. 2005;4(13):1530-40.

16. Draughon F Ann.Use of botanicals as biopreservatives in food. Food Tech. 2004;58(2):20-9.

17. Vasudevan DT, Dinesh KR, Gopalakrishnan S, Sreekanth SK, Sonal S. The potential of aqueous and isolated fraction from leaves of Cassia fistula Linn as antibacterial agent. Int J Chem Sci. 2009;7(4):2363-7.
18. Rizvi MM, El Hassadi IM, Younis SB. Bioefficacies of Cassia fistula: an Indian labrum. African J Pharmacy Pharmacol. 2009 Jun 30;3(6):287-92.

19. Duraipandiyan V, Ignacimuthu S. Antibacterial and antifungal activity of Cassia fistula L.: an ethnomedicinal plant. J Ethnopharmacol. 2007 Jul 25;112(3):590-4.

20. Panda SK, Padhil LP, Mohanty G. Antibacterial activities and phytochemical analysis of Cassia fistula (Linn.) leaf. J Adv Pharm Technol Res. 2011 Jan;2(1):62-7.

21. Senthil Kumar M, Sripriya R, Raghavan V, Sehgal PK, Wound healing potential of Cassia fistula on infected albino rat model. J Surg Res. 2006 Apr;131(2):283-9.

22. Arulpandi I, Sangeetha R. Antibacterial activity of fistulin: a protease inhibitor purified from the leaves of Cassia fistula. ISRN Pharmaceut. 2012 Jun 20;2012.

23. Lachumi SJ, Zuraini Z, Sasidharan S. Antimicrobial activity and toxicity of methanolic extracts of Cassia fistula seeds. Res J Pharm Biol Chem Sci. 2010;13918.

Cite this article as: Kamath BR, Kizhedath S. Invitro antibacterial activity of Cassia fistula Linn methanolic leaf extracts. Int J Basic Clin Pharmacol 2019;8:270-4. 